\title{
Regulatory agencies and courts: interactions between administration and justice
}

\author{
JeOVAN ASSIS DA SILVA ${ }^{1}$ \\ TOMAS AQUINO GUIMARÃES ${ }^{1}$ \\ ${ }^{1}$ Universidade de Brasília (UnB) / Programa de Pós-Graduação em Administração (PPGA), Brasília - DF, BraziL
}

\begin{abstract}
The interrelationships between regulatory agencies and judicial courts generally have a high impact on social relations. However, there is little empirical research and a need for greater systematization of knowledge from a multidisciplinary perspective. This essay discusses the main tensions between the executive and judicial branches of government in decisions about the regulatory activity. The discussion is facilitated through the main theoretical lenses and previous studies on the application to the phenomena. The relationship between agencies and courts is marked by divisions, and the institutional approach to the regulatory space and reflections stimulated by law and economics theory, among other theoretical approaches, are very useful for interpreting institutional tensions in this relationship. The literature on judicial review of regulatory agency decisions points to factors that explain judicial deference or motivate a more prominent role of courts, as well as on topics related to: a) court involvement with technical and scientific issues; b) efficiency and performance; c) calculated behaviors; d) transaction costs; and e) cost-benefit analysis. A research agenda is suggested to explore the perceptions of key players about regulatory disputes, and factors and conditions that explain judicial deference in different contexts.
\end{abstract}

Keywords: Regulatory agencies. Courts. Judicial Review. Judicial Deference. Administration of Justice.

\section{Regulatory agencies and courts: interactions between administration and justice}

\section{Resumo}

As inter-relações entre agências reguladoras e tribunais judiciais constituem tema de alto impacto nas relações sociais em geral, porém, ainda carecem de pesquisas empíricas e maior sistematização do conhecimento, sob uma perspectiva multidisciplinar. Nessa linha, este ensaio tem por objetivo realizar uma discussão articulada das principais tensões entre o Poder Executivo e o Poder Judiciário em decisões inerentes à atividade regulatória, apoiada nas principais lentes teóricas e no estado da arte aplicáveis ao fenômeno. O relacionamento entre agências e tribunais é marcado por dicotomias e a abordagem institucional do espaço regulatório e as reflexões trazidas pela Análise Econômica do Direito, dentre outras lentes de análise, revelam-se bastante úteis para a interpretação das tensões institucionais existentes em tal relacionamento. A literatura sobre revisão judicial de decisões de agências reguladoras aponta pesquisas sobre fatores que explicam a deferência judicial ou motivam um papel mais proeminente dos tribunais, passando também por temas relativos a: a) envolvimento de tribunais com questões técnicas e científicas; b) eficiência e desempenho; c) comportamentos calculados; d) custos de transação; e e) análises de custo-benefício. Propõe-se uma agenda de pesquisa que explore percepções de atores-chave desse ambiente acerca de litígios regulatórios, bem como estudos sobre fatores e condicionantes que explicam a deferência judicial em diferentes contextos.

Palavras-chave: Agências reguladoras. Tribunais. Revisão judicial. Deferência judicial. Administração da Justiça.

\section{Agencias reguladoras y tribunales: interrelaciones entre administración y justicia}

\begin{abstract}
Resumen
Las interrelaciones entre las agencias reguladoras y los tribunales judiciales son un tema de alto impacto en las relaciones sociales en general, pero aún carecen de investigación empírica y una mayor sistematización del conocimiento desde una perspectiva multidisciplinaria. En esta línea, este ensayo tiene como objetivo llevar a cabo una discusión articulada de las principales tensiones entre el Poder Ejecutivo y el Judicial en las decisiones inherentes a la actividad reguladora, con el apoyo de las principales lentes teóricas y el estado de la cuestión aplicable al fenómeno. La relación entre agencias y tribunales se caracteriza por las dicotomías y el enfoque institucional del espacio regulatorio, y las reflexiones aportadas por el análisis económico del derecho, entre otras lentes de análisis, son muy útiles para interpretar las tensiones institucionales existentes en esta relación. La literatura sobre la revisión judicial de las decisiones de las agencias reguladoras apunta a la investigación de factores que explican la deferencia judicial o motivan un papel más prominente de los tribunales, así como de temas relacionados con: a) participación de los tribunales en cuestiones técnicas y científicas; b) eficiencia y performance; c) comportamientos calculados; d) costos de transacción; y e) análisis de costo-beneficio. Se propone una agenda de investigación que explore las percepciones de los actores clave sobre disputas regulatorias, así como estudios sobre factores y condicionantes que expliquen la deferencia judicial en diferentes contextos.
\end{abstract}

Palabras clave: Agencias reguladoras. Tribunales. Revisión judicial. Deferencia judicial. Administración de la justicia. 


\section{INTRODUCTION}

Judicial review of administrative rulings on regulatory matters occurs frequently in western democracies (BIGNAMI, 2016) and the relationship between regulatory agencies and courts is often marked by misalignment, conflicts, and disputes of authority (VIBERT, 2014). Understanding how these players interact with each other in the regulatory process in environments where the institutional designs are evolving (PRADO, 2016) can contribute to a better understanding of how the regulatory state that emerged in the late 20th century works (MAJONE, 1994; LEVI-FAUR, 2005).

Regulatory activity has been the focus of attention of several disciplines, including public administration, law, political science, economics, and sociology (WINDHOLZ, 2018). Regulation has become a distinct field of academic research with theories, concepts, and specialized knowledge of its own (MORGAN and YEUNG, 2007). Although different currents of thought see the regulatory state from different perspectives, some of its main characteristics can be identified (LODGE and WEGRICH, 2012): confidence in regulation justified by an emphasis on efficiency-related values, greater dependence of the state on private suppliers in the provision of public services, and creation of autonomous regulatory agencies to oversee economic activities.

Scholars of public administration have been urged to reflect on the phenomenon of regulation, and to go beyond traditional economic approaches (LODGE and WEGRICH, 2012). Although there are many academic papers that analyze regulatory agencies (JORDANA, FERNÁNDEZ-I-MARÍN and BIANCULLI, 2018), the importance of researching the interactions between agencies, courts, and the legislative branch has been stressed for a long time (NOLL, 1985).

By sharing responsibility for inducing and shaping behaviors with the law, regulatory and judicial systems are intrinsically connected (SCHMIDT, 2005; COHN, 2011; WINDHOLZ, 2018). Regulatory decisions usually have a redistributive function that produces winners and losers and encourages litigation in the courts (DUBASH and MORGAN, 2012). Although the recent literature on regulation has focused on the increasing role of non-government players and self-regulatory processes (BLACK, 2002), this does not negate the importance of the legal perspective on regulation. On the contrary, it stimulates new discussions about the relationship between these players, the state, and the law (MORGAN and YEUNG, 2007).

Research on the relationship between the courts and public administration and also on the extent to which courts defer to decisions of regulatory agencies is common in the U.S., but the North American tradition of delegating normative powers to agencies (SCOTT, 2001) opens up space for research in different empirical and multidisciplinary contexts. This paper is based on the understanding that discussions on judicial control of public administration fall under the broader context of the relationship between the executive and judicial branches of government in contemporary states and are not restricted to the area of law, which often plays the key role in legal aspects of regulation (SCHMIDT, 2004).

Judicial courts become part of the regulatory process when they review rules or intervene more actively in regulatory policies. Consequently, the judiciary has been an important actor in regulatory activity (KINGSBURY and DONALDSON, 2013): a) judicial contestation can be used as an instrument by different interest groups in conflicts; b) courts are called upon to give their opinion on regulatory standards, which influences the process of defining and legitimizing these policies; and c) the judiciary branch is called upon to arbitrate conflicts between different agencies with regulatory functions and can play a pedagogical role for the actors involved, especially in institutional environments that are still being built, as in the case of developing countries.

Examples of these different roles have emerged around the world. The Constitutional Court of Colombia developed a new rationale for regulation in aspects of economic efficiency related to a new water supply system provided by private entities, in addition to requiring greater public participation in regulatory matters (URUEÑA, 2012). Courts in India have been called to take part in a dispute over the control of decision-making processes in the area of telecommunications and have made a better dialogue between different actors involved in regulation possible (THIRUVENGADAM and JOSHI, 2012). In Indonesia, the Constitutional Court was called upon to decide conflicts arising from the privatization of the electricity industry and to restore state powers with regard to the provision of public services (KINGSBURY and DONALDSON, 2013). 
Many regulatory agencies proliferated in Brazil in the wake of a structural change in public administration arising from reforms carried out from 1995 onward to reduce the direct and indirect involvement of the state in economic and social life (PECl, 2014; PRADO, 2016). The Brazilian judicial branch, which under the Federal Constitution of 1988 (Article 5, Item XXXV) has the power to control administrative acts, has routinely been involved in regulatory processes such as: a) deciding arguments for or against the ratification of utility rate increases, with marked differences between decisions of first degree courts and appeal courts (SILVA and COSTA JÚNIOR, 2011); b) complex arbitration processes between the consumer protection bodies and suppliers relating to technical matters in the electricity industry (SAMPAIO and WADA, 2016); c) trying to strike a balance between the public interest in health protection and the private interests of those involved in economic activities in the health care sector (AITH, 2016).

In Brazil, a study sponsored by the National Justice Council (CNJ, 2011) revealed several shortcomings in the model adopted in the country for judicial review of decisions made by regulatory agencies. The model is extremely slow (average time of four years of processing in the judicial branch) and there is legal uncertainty in the judicial review of regulatory decisions, with multiple changes in decisions through cancellations and confirmations during the proceedings. It became clear that judges did not share a clear position in relation to their role in this reviewing activity and were hesitant about the need to call in judicial experts. Judges have little incentive to review such cases, since, with a large backlog of cases before the courts, they are tempted to give priority to simpler cases. Because the decisions made by regulatory agencies are complex, judges seem to avoid facing more substantive issues and issues of principle in judgments, preferring to address formal and procedural issues.

Understanding the reasons for and impact of such dysfunctions involves reflection on the interaction between regulatory agencies and the courts. This discussion goes beyond the debate on the judicialization of public policies, which focuses on the institutional role of judges and courts from the moment they are provoked to deliberate on such policies (COUTINHO, 2013). According to some studies, the possibility of judicial review has major effects on administrative decisions and can trigger defensive behavior on the part of regulatory agencies (LI, 2012; DRAGU and BOARD, 2015). In addition, the judicialization of public policies still focuses on social and constitutional issues, while regulatory matters raise tensions that are yet to be studied (GINSBURG, 2009). Therefore, there is no clear understanding of the factors leading the judiciary to play a more prominent role, or to adopt a posture of deference or self-restraint, in relation to decisions on regulatory matters.

This essay articulates a discussion of the main tensions in the relations between the executive and judiciary branches of government with respect to regulatory activity, as well as viewing the phenomenon through the main theoretical lenses and applying the state of the art of academic works on the subject. Finally, this paper proposes a research agenda to broaden understanding of the interrelationships between courts and regulatory agencies.

\section{THEORETICAL BACKGROUND}

Definitions of regulation vary according to how each field of knowledge addresses the topic and, because it is a comprehensive concept, the literature on the subject has made little progress in addressing conceptual issues and provides only few, rather abstract definitions (KOOP and LODGE, 2015). However, some conceptualizations have gained interdisciplinary approval and are being widely used, including Selznick's definition of regulation as "sustained and focused control exercised by a public agency over activities that are valued by a community" (SELZNICK, 1985, p. 363). Selznick's definition has been criticized for lacking a more systemic view of regulation (LODGE and WEGRICH, 2012).

Regulation can be examined from several theoretical perspectives, among which the following stand out (MORGAN and YEUNG, 2007): public interest theories; private interest theories; and institutional theories. Public and private interest theories have an economic bias and consider regulation from the perspective of market failures, of sectoral issues, or of actions undertaken by players in pursuit of the public interest, with no private or selfish intent, but that end as failures by, for example, allowing regulatory systems to be captured by economic agents (BALDWIN, CAVE and LODGE, 2010). Adaptations of transaction-cost theories and of the principal-agent theory have also been applied to extend research on regulatory 
motivation and strategies (LEVY and SPILLER, 1996; BALDWIN, CAVE and LODGE, 2010). Institutional theories presuppose the need to study regulation as involving more than an activity or agency, focusing on broader institutional dynamics in which the actions and intentions of regulatory actors are immersed (BALDWIN, CAVE and LODGE, 2010; WINDHOLZ, 2018). This discussion is presented below.

\section{The contribution of institutional theory}

According to the sociological institutional approach institutions are social constructs that do not necessarily correspond to organizations, but rather to norms and conventions with the status of rules in social thought and action, which may or may not have a legal background but are seen as guaranteed and legitimate rules (MEYER and ROWAN, 1977; DIMAGGIO and POWELL, 1992). Through this analysis, in the field of regulation, agencies do not operate in an institutional vacuum, and in their quest for prestige and legitimation, they are sensitive to and responsive to signals from other actors, such as courts, legislative committees, the press, and so on (NOLL, 1985).

With an emphasis on the role of organizations and institutions, formal and informal rules guide regulatory studies from an institutionalist perspective (MORGAN and YEUNG, 2007). In this sense, the law and the legal rules in regulatory processes are just another set of rules that coexist with others from other systems and are shaped by different bureaucratic and organizational ethoses. When defining the foundations of regulation, the legal environment may play a role beyond establishing legal doctrines and might operate at both more direct levels - in litigation and in defining legal rules - and less tangible levels, by affecting expectations about the form and operation of regulatory decision-making processes (BLACK, 1997). Therefore, the analysis of decision-making processes in the area of regulation should not be limited to the legal dimension, which cannot adequately capture the various elements and institutional influences involved in such processes. The institutional approach suggests that attention should be paid to extralegal aspects and to the broader cognitive structures of decision-makers (of their understandings and perceptions of environments and decision situations), which may be particularly relevant for empirical research on legal and regulatory processes.

The concept of "regulatory space" (HANCHER and MORAN, 1989) suggests that important resources for maintaining regulatory power and the exercise of regulatory capacities are dispersed or fragmented in society (BLACK, 1997). The regulatory space is a useful analytic construct for describing and analyzing the environments in which regulation takes place (HANCHER and MORAN, 1989; SCOTT, 2001; VIBERT, 2014; WINDHOLZ, 2018) and it organizes the discussion outside the traditional foci of regulatory instruments and techniques.

With regard to the players involved, it is assumed that the regulatory space is not solely made up of government players and public authorities, but it also includes non-government ones over whom the state may have influence, but cannot monopolize regulatory power (HANCHER and MORAN, 1989). However, countries with a Roman-German legal tradition place greater emphasis on the sovereignty of state entities, but, even at governmental level, authority in the regulatory space is scattered and regulation has a polycentric character (WINDHOLZ, 2018). This concept opens up opportunities for understanding the coordination between and responses from these players from the perspective of different values and interests (SCHMIDT, 2004).

Regarding to resources, the concept of regulatory space introduces the idea that different players contribute with important resources for government to exercise regulatory power (information, institutional credibility, political clout, among others). Resources in regulatory regimes are not, therefore, restricted to legal authority and the fact that several actors rely on other types of resources leads to challenging hierarchical concepts of regulation and highlights the interdependence among actors in the regulatory space (SCOTT, 2001). It is important to analyze conflicts in the regulatory space, the resources used to settle them, and how resources are shared among the different institutions involved (HANCHER and MORAN, 1989).

As for the relationships, cooperative and conflicting relationships in the practice of regulation influence how regulatory issues are identified and defined in the regulatory space and how the players involved interact with each other (HANCHER and MORAN, 1989). This space is characterized by complex horizontal relations and negotiated interdependence (SCOTT, 2001). 
Thus, the phenomenon of capture, which has been addressed in studies on regulation in the fields of economics and political science, can also be considered from the perspective of reciprocal behaviors through which regulators and regulated parties engage in exchanges (of information, for example).

A discussion of the concept of regulatory space has been provided recently, based on reflections on contemporary systems of authority (from the perspective of the exercise of power seen as legitimate) in the performance of regulatory activity (VIBERT, 2014). This perspective emphasizes the importance of looking at regulatory activity from different angles and domains of authority, including that of the law in its relationship with technical regulatory bodies. Because a methodological concern was lacking in Hancher's and Moran's initial formulation of the regulatory space concept, Vibert (2014) supports the notion that relationships in the regulatory space should be analyzed at a "meso" level as an intermediate link between the theorization of individual behaviors (which would also comprise individual regulating or regulated organizations) and the behavior of the system as a whole.

In organizational analyses, the regulatory space can be looked at from the following perspectives: a) the concept of "societal sector", which is defined as a set of organizations operating in the same domain and marked by similarities in their products, services, and functions and which have a critical bearing on the performance of a given focal organization (SCOTT and MEYER, 1991); b) the network theory, which examines systems of relationships in which players have different roles and how the nature of those relationships impacts behaviors and influences the outcome of public policies (ROWLEY, 1997; BERRY, BROWER, CHOI et al., 2004); and c) the stakeholder theory, which explains how organizations respond to other stakeholders in the context of interdependent relationships and how these players influence the goals of a given organization (GOMES, LIDDLE and GOMES, 2010). Regulators, regulated parties, and courts must interpret regulation and adjust themselves to changes in the regulatory environment, so it is timely to investigate which factors mitigate or maximize divergences in interpretation in this network of actors (RANDOLPH and FETZNER, 2018).

The concept of regulatory space provides fertile ground for discussing the interactions between regulatory agencies and the judiciary, as it suggests that not only information and resources are unevenly dispersed among players, but both formal authority (derived from legal instruments) and informal authority (derived from experience and information) are also fragmented. Despite claiming the right to deliberate on administrative matters in the last instance, courts might lose sight of the fact that regulatory authority is increasingly dispersed and that arbitrariness in this field can also be prevented through other channels (MCDONALD, 2004). The volume and technicality of regulatory rules lead to challenging situations in which defending legality, while important, is not always a core role, largely due to the risk of legal discretion compromising the predictability that is often desired in regulatory contexts.

A broad discussion of the interactions between regulatory agencies and courts must also address the different rationalities governing those institutions, which are particularly focused on other works of the regulatory literature. The discussion is presented in the following section.

\section{The different rationalities governing regulatory agencies and courts}

The law and economics approach highlights distinctions between regulatory agencies and courts. The law acts as a facilitator of exchange processes in society, as can remove impediments to private contracts by internalizing certain transaction costs (COOTER and ULEN, 2012). According to Coase's Theorem (COASE, 1960), the relationship between regulatory agencies and courts is initially skeptical about the presence and interference of regulatory agencies (KESSLER, 2010). But this initial objection did not preclude further theoretical refinements that challenge the role of courts and saw judicial intervention as costly and even inappropriate (KESSLER, 2010; SHLEIFER, 2010). Mixed models under which agencies and courts control regulation jointly create disadvantages such as slowness and duplication of costs, but these disadvantages are not be entirely disabling, as the two systems can be complementary (POSNER, 2010).

Certain dimensions of conflict can be identified in the regulatory regimes enforced by agencies and courts (POSNER, 2010): agencies tend to use preventive control and monitoring mechanisms, while courts apply intervention methods and tend to act retrospectively on violations or damages already suffered; agencies usually deal with clear rules, while courts deal with 
more open legal standards that are liable to more subjective interpretation; agencies carry out their work under the auspices of experts, while courts are composed of judges with a more generalist profile and background in law.

As a general rule, regulatory agencies rely on greater expertise for judging technical disputes than courts, which are usually more familiar with legal-procedural issues. Regulatory agencies are usually in a better position to mobilize relevant knowledge and information in their work and this expertise is more appropriate than that available to courts, although regulatory agencies have also been criticized for being overly dependent on information provided by regulated parties (HALL, SCOOT and HOOD, 2000). Opportunities may be available for the judiciary to elicit technical input from experts brought by the parties to refute or defend analyses and evidence, but this procedure can be fragile and prone to manipulation in some cases (POSNER, 2010).

By analyzing specific disputes and focusing on the parties to a particular dispute, courts are unable to evaluate objectives and outcomes of wider regulatory issues (KNIGHT and JOHNSON, 2007). Regulators shape their actions broadly for an industry or economic sector as a whole, while courts are limited to the unique features of a concrete case (POSNER, 2010). As a result, conflicts arise over decisions on particular cases and over the inherently generalist nature of regulatory decisions and policies (SCHAUER and ZECKHAUSER, 2010).

The plural nature of administrative and judicial regulatory proceedings - which are marked by imperfect decision-making and complex technical disputes - suggests that comparative institutional analysis should be undertaken in studies of the interaction between regulatory agencies and the judiciary (MANTZARI, 2016). Based on a theory of comparative institutional analysis (KOMESAR, 1997), it is suggested that, unlike the market and the political system, courts have unique attributes and formal requirements that limit the information judges receive and restrict their decision-making capacity. Courts should therefore be cautious about market or political decisions when the balance of biases or competences encourages an attitude of deference. However, this self-restraint can in some cases be made more flexible by other institutional factors, such as by specialized courts (MANTZARI, 2016).

The occurrence of such self-restraint or judicial deference in regulatory matters has been studied extensively in North America and in a range of specific situations. Factors leading to greater deference by courts may include: the degree of insulation and time in operation of the regulatory agency (MEAZELL, 2012); the reputation of the regulatory agency (MAGGETTI and PAPADOPOULOS, 2016); the excessive complexity of cases, which may even encourage "superdeference" on certain issues (MEAZELL, 2011); the thematic area of action and strategic behavior of the agencies with a view to anticipating future judicial decisions (MAGILL and VERMEULE, 2011). There would be less judicial deference in cases of ideological divergence between regulatory agencies and courts, especially when the regulatory body reviews its own position over time (GIVATI and STEPHENSON, 2011).

\section{State of the art of the interaction between regulatory agencies and courts}

Theoretical-empirical papers published in peer-reviewed journals between 2010 and July 2018 were selected for review. In this review, difficulties similar to those pointed out by Osorio and O'Leary (2017) were faced in conducting a literature review on the relationship between courts and the public administration. According to those authors, there are few studies on the subject in the social science literature in general and, in particular, in public administration journals. This discussion is more frequently addressed in legal journals and it can have the following weaknesses: a predominantly normative focus on jurisprudence and on the convenience of judicial intervention; little use of empirical data, and when such data is used, it is often for the purpose of corroborating doctrinal arguments; and excessive self-reference as a result of scant dialogue with studies involving other social sciences.

The following keyword search terms were used (and translated into Portuguese or Spanish when necessary):

- "regulatory agencies" or "administrative law" and "judicial review" or "court*" or "judicial*").

The searches were conducted in the Spell, Scielo, SAGE, Scopus, JSTOR, and Web of Science databases. The title and abstract of the identified papers were read and those that consisted only in theoretical discussions and analysis of jurisprudence or precedents were discarded. As a result of this filtering process, 10 theoretical-empirical papers were found, confirming that little research has been carried out into the role of courts in the area of regulation (LEVI-FAUR, 2011) and the existence of aspects that are yet to be appropriately explored academically in this area (DUBASH and 
MORGAN, 2012; PRADO, 2016; WINDHOLZ, 2018). Seven papers were added to the initial 10 using the "snowball" technique, based on checking their references. After those 17 papers were read and analyzed, the main research results were grouped under the themes listed below.

\section{Judicial deference}

One research analyzed ten empirical studies on judicial review of actions of regulatory agencies according to six different judicial doctrines or precedents (PIERCE, 2011). The decisions of regulatory agencies were confirmed by federal courts in a high number of cases (in approximately 70 percent of cases), regardless of the doctrine invoked in the specific case. Therefore, variations in confirmation in judicial reviews would need to be explained by other factors, such as the following: procedural basis of the agency's decision; consistency of the position of the agency over time; judicial familiarity with the subject matter of the decision and ideological preferences of the judges involved.

Another paper challenges the dichotomy of applying judicial deference to decisions of regulatory agencies (FIX, 2014). According to this author, the political importance of the substantive issue being examined by the judiciary is a factor that adds complexity to the interactions between courts and agencies. The research was based on a sample of 852 cases decided upon between 1961 and 2002 using logistic regression. The results show that the level of deference is constant for "less important" cases, while for "prominent" cases it is strongly related to ideological compatibility between the court and the agency involved.

\section{Judicial behavior}

Three papers focused primarily on factors in regulatory systems that require the judiciary to play a more prominent role in regulation, especially to investigate the motivation of judges in cases involving regulation. The judiciary can play unconventional support roles by fostering communication and interaction between several regulatory institutions and assuming a pedagogical stance by reviewing the role of newly-established regulatory institutions (URUEÑA, 2012) or requesting explanations from the executive branch of government for the lack of a regulatory agency (THIRUVENGADAM and JOSHI, 2012). Similarly, an empirical case study addressed the involvement of Chinese courts in dealing with environmental regulatory issues to try and understand the reasons for such involvement and how it affected the behavior of regulated parties (ZHANG, 2016). Research of this kind develops case studies, is more descriptive, and makes theoretical comparisons based on regulation and theories of judicial behavior.

\section{Involvement of courts in technical and scientific issues}

Some papers discuss how the judiciary deals with regulatory issues where technical and scientific aspects are crucial. A study examined how the Colombian Supreme Court has played a proactive role in relation to health care issues, for example, decisions about drug efficacy and mandatory health care coverage by health insurance plans, often disregarding budgetary and financial arguments (HAWKINS and ALVAREZ ROSETE, 2017). In this investigation, the researchers conducted content analysis of interviews. A Brazilian study analyzed judicial control of a regulatory standard adopted by the National Health Agency for coverage of medical emergencies in health care plans (RAMALHO, 2016). A review of the jurisprudence of appellate decisions of three courts of justice was carried out and the results show that judicial control was exercised in such a way that agency standards were systematically disregarded, leading to inter-institutional friction.

A third study pointed out that the increasing and rigorous engagement of courts in environmental regulation may lead to a constructive partnership between courts and agencies on complex scientific issues (FISHER, PASCUAL and WAGNER, 2015). The courts could act as necessary critics, encouraging regulatory agencies to develop more solid accountability and governance mechanisms that would in turn improve judicial reviews and make them more focused and consistent in a positive symbiotic relationship for both parties.

Another study (BAYE and WRIGHT, 2011) focused on the problem of lack of preparation of the judiciary to deal with antitrust issues, which increasingly require sophisticated predictions and calculations. The authors state that the economic complexity of cases increases the likelihood of appeals being filed, and that training judges is effective for simple proceedings, but less so 
for complex cases. The research also found that repeated exposure of judges to complex cases is not a substitute for training. Therefore, the usual procedure of establishing specialized courts is not as effective as one might think, as providing more advanced training and the assignment of experts by courts would have a more significant impact.

\section{Efficiency and performance in mixed regulatory models (involving regulatory agencies and courts)}

Two papers analyzed issues related to efficiency and performance in regulatory institutional designs characterized by the coexistence of regulatory agencies and courts. In litigation brought before courts against decisions of twelve Croatian regulatory agencies, rulings issued between 1995 and 2011 were analyzed (BAJAKIĆ and KOS, 2016). Aspects such as the winning party, percentage of success, costs involved, and duration of the proceedings were analyzed. Regulatory agencies won $82 \%$ of the cases and trend analysis indicated that they have been increasingly successful in confirming the legality of their decisions. This result is in line with the findings of other studies according to which there is a positive correlation between the technical or economic complexity of a regulatory proceeding and the percentage of court rulings in favor of regulatory agencies. A different path was suggested in a study that compared decisions by federal judges and commissioners of the Federal Trade Commission that went to federal appellate courts under US antitrust law (WRIGHT and DIVELEY, 2013). The study tested whether the presumed higher degree of expertise involved in decisions of regulatory agencies would translate into fewer reversal decisions by the judiciary. The result indicated that the Commission's decisions were more likely to be both appealed against and annulled by a federal court.

\section{Calculated behaviors}

A set of studies drew attention to the possibility that regulatory agencies and litigants modulate their conduct in response to expectations about judicial positioning or for their own benefit. A study in Brazil investigated the behavior of regulated companies operating in the electricity supply industry (MONTEIRO, RAVENA and CONDE, 2013). It identified the problem of competing regulatory instances that favor judicialization of public policies and procrastinating behavior, reducing the effectiveness of regulatory instruments. It found that there was a dysfunctional framework that allows enterprises to escape or postpone sanctions arising from non-compliance with contractual requirements.

Wagner (2010), based on a case study of the US Environmental Protection Agency, pointed to risks stemming from judicial oversight when courts are exposed to excessive information from parties attempting to capture and control the regulatory process. Rather than contributing to settling technical regulatory issues, collecting excessive and often complex information may involve calculated behavior that ends up discouraging substantive review by courts.

Another study indicated that regulatory agencies can avoid exposing themselves to judicial review by not bringing to justice cases with little chance of success due to contrary (LI, 2012). Much of the literature focuses on the outcome of administrative proceedings examined by courts, but in this case the author analyzed procedures and investigations (carried out by an antitrust agency) that were closed at the administrative level. Using a statistical model of decisions issued by the US antitrust department between 1940 and 1994, the research concluded that regional courts, whose rulings vary more intensely, creating legal uncertainty, significantly reduced the willingness of the agency to seek judicial prosecution.

\section{Transaction costs and cost-benefit analysis}

One study analyzed the interaction between the judiciary and regulatory policy from the perspective of transaction costs (SILVA and COSTA JÚNIOR, 2011). The research left aside negative evaluations of judicial intervention and was based on the understanding that such approaches neglect the heterogeneity of preferences in courts. Based on a case study of a rate increase authorized by the Brazilian National Telecommunications Agency and contested in the courts, the authors proposed a model that took into account institutional characteristics of the judiciary and preferences of judges (such as more or less interventionist postures). The paper concluded that the judiciary has internal controls, particularly applied by its higherranking bodies, that can complement and reaffirm certain regulatory policies.

Two studies explored institutional design from the point of view of cost-benefit analysis based on a comparison of regulatory bodies operating in the environmental and financial sectors, in connection with the activities of an agency in charge of 
supervising federal regulation and judicial review (REVESZ, 2016). A specific case is discussed in which, in addition to the friction between regulatory agencies and courts, double reviews (by both the supervising agency and the judiciary) were carried out that had a negative impact on regulation, especially in the financial sector, which is less mature than the environmental sector. The findings of another cost-benefit analysis, covering both regulatory agencies and administrative courts in charge of other functions, identified a cooperative role on the part of courts, suggesting that judicial review is a positive procedure (GELBACH and MARCUS, 2017). According to these findings, courts carry out a "problem-oriented oversight" through which dysfunctions in the work of administrative agencies can be mitigated.

\section{CONCLUSIONS AND RECOMMENDATIONS}

The functioning of the regulatory state (MAJONE, 1994; LEVI-FAUR, 2005) and its impact on public administration require in-depth understanding of the interactions between regulatory agencies and courts. This is an important discussion from the economic and social point of view, since regulatory decisions impact on citizens' daily life, and the topic requires more empirical and systematic research, especially in developing countries (GINSBURG, 2009; DUBASH and MORGAN, 2012). The discussion presented in this essay shows that although there are many problems with the interactions between the judiciary and regulatory agencies, the academic research agenda has not kept up with the topic in field research. We draw attention to the theoretical complexity of debates on judicial control and to the scarcity of empirical studies on how judicial review of administrative decisions is actually determined, especially from perspectives external to the legal sphere.

As discussed in this essay, the regulatory space is a very useful analytical construct for describing and analyzing the environments in which regulation takes place (HANCHER and MORAN, 1989; SCOTT, 2001; VIBERT, 2014; WINDHOLZ, 2018) and it organizes the discussion beyond the traditional foci on regulatory instruments and techniques. The different organizations dealing with regulation need to address the dispersion of regulatory power in the complex relationships that are marked by conflicting perceptions and preferences (SCOTT, 2001; VIBERT, 2014). In this sense, the following proposition is presented:

- Proposition 1: The overlapping of authority in the regulatory space leads to conflicts between legal control by courts and the application of regulatory standards by regulatory agencies.

Complementing the contributions which institutional theory makes to understanding the phenomenon, the legal and economic approaches also provide elements for discussing the relationship between regulatory agencies and courts, emphasizing the tensions between technical-administrative and legal rationalities, and the different standards adopted by agencies and courts for interpreting regulatory matters. There is, therefore, a conflict in court decisions about specific cases and the broader character of regulatory objectives and policies (POSNER, 2010; SCHAUER and ZECKHAUSER, 2010). Consequently, we suggest the following proposition:

- Proposition 2: Judicial review of decisions made by regulatory agencies involves conflicts of choice between regulatory and adjudicatory processes and technical-administrative and legal rationalities.

These propositions point to several possibilities for empirical research. Qualitative studies can help to understand how judges perceive their role in regulatory contexts and how these perceptions affect their decisions. Conversely, another important approach would be to examine how technical experts, officials and lawyers of the agencies perceive the consequences of regulatory disputes in their work. As the CNJ study (2011) pointed out, sluggishness and unpredictability in the judicial system significantly affect the work and policies developed by technical experts.

From the perspective of a quantitative approach, this is a timely moment to investigate the factors and constraints that explain judicial deference. Conflicts between technical-administrative and legal rationality can be explored through research into factors and contexts that maximize or minimize divergence in regulatory interpretation in the institutional-legal environment. The review carried out here shows that certain factors can have a decisive impact on how regulatory disputes are addressed by the judiciary. These include institutional characteristics of regulatory agencies and courts and sectoral or thematic variations in regulation. 
The main themes emerging from the discussion of the state of the art above, may suggest self-restraint or greater prominence on the part of courts, so it is necessary to check and refine the influence of these and other variables in the Brazilian context. Such research can be based on documentary analysis of cases brought before Brazilian federal courts involving regulatory agencies. The results of such research can be used to build a database and construct statistical models that may generate possible predictors of judicial deference in the Brazilian context or, on the other hand, lead the judiciary to play a more prominent role in the context of regulation. A content analysis of these judicial decisions, with the support of text mining techniques, could also be important for studying factors that influence judicial decisions involving regulatory matters in Brazil. 


\section{REFERENCES}

AITH, F. Agências reguladoras de saúde e Poder Judiciário no Brasil: uma relação conflituosa e necessária para a garantia plena do direito à saúde. In: PRADO, M. M. (Org.). O Judiciário e o Estado regulador brasileiro. São Paulo: FGV Direito SP, 2016. p.209-230. x-y.

BAJAKIĆ, I.; KOS, V. What can we learn about regulatory agencies and regulated parties from the empirical study of judicial review of regulatory agencies' decisions? The case of Croatia. Central European Journal of Public Policy, v. 10, n. 1, p. 22-34, 2016.

BALDWIN, R.; CAVE, M.; LODGE, M. Introduction: regulation - the field and the developing agenda. In: BALDWIN, R.; CAVE, M.; LODGE, M. (Ed.). Oxford handbook of regulation. Oxford: Oxford University Press, 2010. p. 5-17.

BAYE, M.; WRIGHT, J. Is Antitrust too complicated for generalist judges? The impact of economic complexity and judicial training on appeals. Journal of Law and Economics, v. 54, n. 1, p. 1-24, 2011.

BERRY, F. S. et al. Three traditions of network research: what the public management research agenda can learn from other research communities. Public Administration Review, v. 64, n. 5, p. 539-552, 2004.

BIGNAMI, F. Introduction: a new field - comparative law and regulation. In: BIGNAMI, F.; ZARING, D. (Ed.). Comparative law and regulation: understanding the global regulatory process. Cheltenham: Edward Elgar, 2016. p.1-55.

BLACK, J. New institutionalism and naturalism in socio-legal analysis: institutionalist approaches to regulatory decision making. Law and Policy, v. 19, n. 1, p. 52-56, 1997.

BLACK, J. Decentring regulation: understanding the role of regulation and self-regulation in a "post-regulatory" world. Current Legal Problems, v. 54, p. 103-146, 2002.

COHN, M. Law and regulation: the role, form and choice of legal rules. In: LEVI-FAUR, D. (Ed.). Handbook on the politics of regulation. Cheltenham: Edward Elgar, 2011. p.185-200.

CONSELHO NACIONAL DE JUSTIÇA - CNJ. As inter-relações entre o processo administrativo e o judicial, sob a perspectiva da segurança jurídica do plano da concorrência econômica e da eficácia da regulação pública. 2011. Available at: <http://www.cnj.jus.br/images/ pesquisasjudiciarias/Publicacoes/relat_pesquisa_usp_edital1_2009. pdf>. Acessed on: July 01, 2018.

COOTER, R.; ULEN, T. (Ed.). Law and economics. 6. ed. Cranbury, NJ: Addison-Wesley Longman, 2012.

COUTINHO, D. O direito nas políticas públicas. In: MARQUES, E.; FARIA, C. (Org.). Política pública como campo multidisciplinar. São Paulo: Ed. UNESP, 2013. p.181-200.

DIMAGGIO, P.; POWELL, W. (Ed.). The new institutionalism in organizational analysis. Chicago: University of Chicago Press, 1992.

DRAGU, T.; BOARD, O. On judicial review in a separation of powers system. Political Science Research and Methods, v. 3, n. 3, p. 473492, 2015.

DUBASH, N.; MORGAN, B. Understanding the rise of the regulatory State of the South. Regulation \& Governance, v. 6, n. 3, p. 261-281, 2012.
FISHER, E.; PASCUAL, P.; WAGNER, W. Rethinking judicial review of expert agencies. Texas Law Review, v. 93, p. 1681-1721, 2015.

FIX, M. P. Does deference depend on distinction? Issue salience and judicial decision-making in administrative law cases. Justice System Journal, v. 35, n. 2, p. 122-138, 2014.

GELBACH, J. B.; MARCUS, D. Rethinking judicial review of high volume: agency adjudication. Texas Law Review, p. 1097-1162, 2018.

GINSBURG, T. Judicialization of administrative governance: causes, consequences and limits. In: GINSBURG, T.; CHEN, A. (Ed.). Administrative law and governance in Asia: comparative perspectives. New York: Routledge University Press, 2009. p. 1-19.

GIVATI, Y.; STEPHENSON, M. Judicial deference to inconsistent agency statutory interpretations. The Journal of Legal Studies, v. 40, n. 1, p. 85-113, 2011.

GOMES, R. C.; LIDDLE, J.; GOMES, L. O. M. A five-sided model of stakeholder influence. Public Management Review, v. 12, n. 5, p. 701-724, 2010.

HALL, C.; SCOTT, C.; HOOD, C. Telecommunications regulation: culture, chaos and interdependence inside the regulatory process. London: Routledge, 2000.

HANCHER, L.; MORAN, M. Organizing regulatory space. In: HANCHER, L.; MORAN, M. (Ed.). Capitalism, culture and economic regulation. Oxford: Clarendon Press, 1989. p. 271-300.

HAWKINS, B.; ALVAREZ ROSETE, A. Judicialization and health policy in Colombia: the implications for evidence-informed policymaking. Policy Studies Journal, v. 47, n. 4, p. 953-977,, 2019.-

JORDANA, J.; FERNÁNDEZ-I-MARÍN, X.; BIANCULLI, A. Agency proliferation and the globalization of the regulatory State: introducing a data set on the institutional features of regulatory agencies. Regulation \& Governance, v. 12, n. 1, p. 1-17, 2018.

KESSLER, D. Introduction. In: KESSLER, D. (Ed.). Regulation vs. litigation: perspectives from economics and law. Chicago: University of Chicago Press, 2010. p.1-9.

KINGSBURY, B.; DONALDSON, M. Roles of Law in Regulatory States of the South. In: DUBASH, N.; MORGAN, B. (Ed.). The rise of the regulatory State of the South. Oxford: Oxford University Press, 2013. p. 256-266.

KNIGHT, F.; JOHNSON, J. The priority of democracy: a pragmatist approach to political-economic institutions and the burden of justification. The American Political Science Review, v. 101, n. 1, p. 57-61, 2007.

KOMESAR, N. Imperfect alternatives: choosing institutions in law, economics and public policy. Chicago: University of Chicago Press, 1997.

KOOP, C.; LODGE, M. What is regulation? An interdisciplinary concept analysis. Regulation and Governance, v. 11, n. 1, p. 95-108, 2015.

LEVI-FAUR, D. The global diffusion of regulatory capitalism. The Annals of the American Academy of Political and Social Science, v. 598, p. 12-32, 2005. 
LEVI-FAUR, D. Regulation and regulatory governance. In: LEVI-FAUR, D. (Ed.). Handbook on the politics of regulation. Cheltenham: Edward Elgar, 2011. p. 3-21.

LEVY, B.; SPILLER, P. A framework for resolving the regulatory problem. In: LEVY, B.; SPILLER, P. (Ed.). Regulation, institutions and commitment. Cambridge: Cambridge University Press, 1996. p. 1-35.

$\mathrm{LI}, \mathrm{Q}$. To prosecute or not to prosecute, that is the question: agency litigation under the influence of appellate courts. Canadian Journal of Political Science, v. 45, n. 1, p. 185-205, 2012.

LODGE, M.; WEGRICH, K. Managing regulation: regulatory analysis, politics and policy. New York: Palgrave Macmillan, 2012.

MAGGETTI, M.; PAPADOPOULOS, Y. The principal-agent framework and independent regulatory agencies. Political Studies Review, v. 14, n. 4, p. 1-12, 2016.

MAGILL, E.; VERMEULE, A. Allocating power within agencies. The Yale Law Journal, v. 120, n. 5, p. 1032-1083, 2011.

MAJONE, G. The rise of the regulatory State in Europe. West European Politics, v. 17, p. 77-101, 1994.

MANTZARI, D. Economic evidence in regulatory disputes: revisiting the court-regulatory agency relationship in the US and in the UK. Oxford Journal of Legal Studies, v. 35, n. 3, p. 565-594, 2016.

MCDONALD, L. The rule of law in the "new regulatory State". Common Law World Review, v. 33, n. 3, p. 197-221, 2004.

MEAZELL, E. Super deference, the science obsession, and judicial review as translation of agency science. Michigan Law Review, v. 109, n. 5, p. 733-784, 2011.

MEAZELL, E. Presidential control, expertise, and the deference dilemma. Duke Law Journal, v. 61, n. 8, p. 1763-1810, 2012.

MEYER, J. W.; ROWAN, B. Institutionalized organizations: formal structure as myth and ceremony. American Journal of Sociology, v. 83, n. 2, p. 340-363, 1977.

MONTEIRO, M.; RAVENA, N.; CONDE, C. Judicialização da regulação e perda da qualidade do fornecimento de energia elétrica em áreas periféricas. Revista de Administração Pública, Rio de Janeiro, v. 47, n. 2, p. 403-419, 2013.

MORGAN, B.; YEUNG, K. An introduction to law and regulation: text and materials. Cambridge: Cambridge University Press, 2007.

NOLL, R. G. Introduction. In: NOLL, R. G. (Ed.). Regulatory policy and the social sciences. Berkeley: University of California Press, 1985. p.3-8.

OSORIO, A.; O'LEARY, R. The impact of courts on public management: new insights from the legal literature. Administration \& Society, v. 49, n. 5 , p. 658-678, 2017.

PECl, A. Regulação e administração pública. In: Guerra, S. (Org.). Regulação no Brasil: uma visão multidisciplinar. Rio de Janeiro: Ed. FGV, 2014. P 57-80.

PIERCE, R. J. What do the studies of judicial review of agency actions mean? Administrative Law Review, v. 63, n. 1, p. 77-98, 2011.

POSNER, R. Regulation (agencies) versus litigation (courts): an analytical framework. In: KESSLER, D. (Ed.). Regulation vs. litigation: perspectives from economics and law. Chicago: University of Chicago Press, 2010. p. 11-26.
PRADO, M. M. Introdução. In: PRADO, M. M. (Org.). O Judiciário e o Estado regulador brasileiro. São Paulo: FGV Direito SP, 2016. p. 7-22.

RAMALHO, B. A. A interface institucional entre a ANS e o Poder Judiciário: análise de acórdãos sobre a cobertura de emergências médicas em planos de saúde. Revista de Direito Sanitário, v. 17, n. 1, 2016.

RANDOLPH, G.; FETZNER, J. Regulatory interpretation: regulators, regulated parties, and the courts. Business and Politics, v. 20, n. 2, p. 301-328, 2018.

REVESZ, R. L. Cost-benefit analysis and the structure of the administrative State: the case of financial services regulation.Yale Journal on Regulation, n. 34, p. 545-600, 2017.

ROWLEY, T. J. Moving beyond dyadic ties: a network theory of stakeholder influences. Academy of Management Review, v. 22, n. 4, p. 887-910, 1997.

SAMPAIO, P.; WADA, R. A regulação e o Judiciário: o caso do setor de eletricidade. In: PRADO, M. M. (Org.). O Judiciário e o Estado regulador brasileiro. São Paulo: FGV Direito SP, 2016. p. $135-160$.

SCHAUER, F.; ZECKHAUSER, R. The trouble with cases. In: KESSLER, $D$. (Ed.). Regulation vs. litigation: perspectives from economics and law. Chicago: University of Chicago Press, 2010. p. 45-70.

SCHMIDT, P. Law in the age of governance: regulation, networks and lawyers. In: JORDANA, J.; LEVI-FAUR, D. (Ed.). The politics of regulation: institutions and regulatory reforms for the age of governance. Chelteham: Edward Elgar, 2004. p. 273-295.

SCHMIDT, P. Lawyers and regulation: the politics of the administrative process. Cambridge: Cambridge University Press, 2005.

SCOTT, C. Analysing regulatory space: fragmented resources and institutional design. Public Law, Summer, p. 329-353, 2001.

SCOTT, W. R.; MEYER, J. W. The organization of societal sectors: propositions and early evidence. In: POWELL, W. W.; DIMAGGIO, P. J. (Ed.). The new institutionalism in organizational analysis. Chicago: University of Chicago Press, 1991. p. 108-140.

SELZNICK, P. Focusing organizational research on regulation. In: NOLL, R. G. (Ed.). Regulatory policy and the social sciences. Berkeley: University of California Press, 1985. p.363-368.

SHLEIFER, A. Efficient regulation. In: KESSLER, D. (Ed.). Regulation vs. litigation: perspectives from economics and law. Chicago: University of Chicago Press, 2010. p. 27-43.

SILVA, R. S.; COSTA JÚNIOR, A. P. S. Judiciário e política regulatória: instituições e preferências sob a ótica dos custos de transação. Revista de Economia Política, v. 31, n. 4, p. 659-679, 2011.

THIRUVENGADAM, A.; JOSHI, P. Judiciaries as crucial actors in southern regulatory systems: a case study of Indian telecom regulation. Regulation \& Governance, v. 6, p. 327-343, 2012.

URUEÑA, R. The rise of the constitutional regulatory State in Colombia: the case of water governance. Regulation and Governance, v. 6, n. 3, p. 282-299, 2012. 
VIBERT, F. The new regulatory space: reframing democratic governance. Chelteham: Edward Elgar, 2014.

WAGNER, W. Administrative Law, Filter Failure, and Information Capture. Duke Law Journal, v. 59, p. 1321-1432, 2010.

WINDHOLZ, E. Governing through regulation: public policy, regulation and the law. New York/London: Routledge, 2018.
WRIGHT, J. D.; DIVELEY, A. M. Do expert agencies outperform generalist judges? Some preliminary evidence from the Federal Trade Commission. Journal of Antitrust Enforcement, v. 1, n. 2, p. 82-103, 2013.

ZHANG, X. Judicial enforcement deputies: causes and effects of Chinese judges enforcing environmental administrative decisions. Regulation \& Governance, v. 10, p. 29-43, 2016. 